Sánchez Ballesteros Vanesa*

https://orcid.org/0000-0002-4697-7891
UDK: 336.22(460+4-672EU)

Original scientific paper

DOI: $10.5937 /$ ptp2104033S

Received: 07.11.2021.

Approved on: 29.11.2021.

Pages: $33-41$

\title{
SPANISH SPECIAL TAXES AND \\ THE TAX HARMONIZATION OF THE EUROPEAN UNION
}

\begin{abstract}
If the special taxes have been imposed with a fundamental objective of promoting a consumption limitation of certain products derived from their devastating social or environmental impact, it is necessary to reflect on their high cost produced by the transposition of the EU Directive 2020/262 of the Council, from December 19th, 2019, which establishes a general regime of special taxes and their taxation. If the objective of the aforementioned Directive is to achieve a fiscal harmonization, it is necessary to consider the effects that occur when its application in the Spanish state directly collides with the economic capacities and tax justice, since these principles may be void of a content and threaten to a greater or lesser extent against another basic non-confiscatory tax collection. For this reason, this work will analyze some issues related to its high quantification and the results produced in the EU harmonization line. Taking into account that our constitutional principles may be called into question, there will be raised various questions about a double taxation of the products affected by these taxes, and, how, in its social repercussion, it does not seem to comply with its alleged extra-taxation in terms of its effectiveness.
\end{abstract}

Keywords: special tax, extra-tax, confiscatory, harmonization.

\footnotetext{
${ }^{*}$ LLD, The Department of Civil, Financial and Tax law, The University of Jaén (Spain), e-mail: vballest@ujaen.es

(c) () (C) 2021 by the authors. This article is an open access article distributed under the terms and conditions of the Creative Commons Attribution (CC BY) license (https://creativecommons. org/licenses/by/4.0/).
} 


\section{Introduction}

Taxes, in their most elementary conception, are the fundamental instruments for sustaining the public expenditures of a State since they provide the population with the services necessary for the achievement of the well-being of society, having a direct impact on maintaining it in its own right political, economic and social dimension. However, if we talk about special taxes, in addition to being collection instruments, they have a much more specific function, since they try to tax products that, due to their special nature, can have a negative impact on both the environment and society. However, these special taxes are indirect taxes that significantly tax the product, justified by the extrafiscal function of the tax, that is, a function that tries to discourage consumption, although it will not always produce the desired effect. Consequently, here the implementation in the Spanish State is proposed as a consequence of the transposition of Directive 2008/118 of the Council of December 16, 2008 , which establishes the general regime of special taxes, in terms of its regime harmonization of Member States. This community transposition, as well as those specific to energy products and electricity (Directive 2003/96/ $\mathrm{CE}$ ); alcohol and alcoholic beverages (regulated by Directives 92/83/CEE and 92/84/CEE); and tobacco products (regulated by Directive 2011/64 / EU) can jeopardize such important fiscal principles as tax justice and economic capacity, since they are applied directly to consumption and to a high degree.

\section{Methodology}

In this article, a brief overview of the legal regime of excise taxes will be made, not only the basic aspects of the Spanish legal regime but also its European dimension. Subsequently, its extra-fiscal function and whether or not this occurs will be analyzed. The structure of special taxes and their scope of application will be analyzed, and the intended fiscal harmonization of the European area and its repercussion with the tax principles of the Spanish State will be questioned.

Finally, the possible consideration of the confiscatory nature of the tax will be raised and it will conclude with the hypotheses that have given rise to the study and possible future lines of research on the subject in question. 


\section{Special taxes: concept and legal regulation in Spain-European Union}

To start talking about special taxes, it is necessary to point out what a tax system means and its objective. Our supreme rule, the Spanish Constitution (1978), establishes as an obligation of all citizens, both Spanish and foreigners, the support of social spending through taxes, included in article 31.1, where it also adds that such circumstance must be weighted based on their economic capacity through a fair tax system, supported by principles of equality and progressivity, eliminating any confiscatory feature. The meaning of this declaration means that everyone who has any professional activity in Spanish territory must contribute to the public coffers, simply due to the fact that the taxable event typified by the legislator occurs, derived from an act or legal-economic business. In this way and according to the Spanish constitutional essence, each taxpayer must contribute only what they have the economic capacity to face (Sainz de Bujanda, 1991, p. 107). As a note, the Constitutional Court has repeatedly declared that taxes ${ }^{1}$ are an instrument of general economic policy that fulfill the essential objective of collecting income and above all, ensuring an equitable distribution of wealth (STC 46/2000, of February 17; 276 / 2000, of November 16). Consequently, the Professor of Financial and Tax Law (López, 2020a, p. 91), insists on this issue throughout his works, relating articles 1.1, 31.1 and 131.1 of our Spanish Constitution, where he determines that as a social and democratic State of Law Income and public spending are distributed towards a social dimension of the State, thus justifying a just distribution of wealth.

\subsection{Special taxes: national and European legal concept and regime}

According to the General Tax Law (2003), in its article 2.2.c, the tax is a tribute that is required of the citizen without any consideration when a taxable event occurs through patrimonial businesses, taking into account the economic capacity of the subject. It also adds a list of both direct and indirect taxes such as: Personal Tax, Corporation Tax, Tax on Economic Activities (VAT), Tax on Patrimonial Transmissions, etc., detailing a wide list. But within its list it also includes a section on Special Taxes, this being the subject at hand.

According to Law 38/1992, of December 28, on Special Taxes, in its article 1, the special tax is expressly defined as a tax of an indirect nature that

1 The concept of tribute is defined as a general notion that includes taxes, fees and special contributions. 
falls on certain consumptions and levies only one phase, either manufacturing, importation or territorial introduction. These products or goods subject to these taxes are hydrocarbons, coal, electricity, means of transport, tobacco products, alcohol, wine, beer and fermented beverages. In other words, it taxes products that may have a negative impact on society, as stated in the explanatory memorandum of this aforementioned Law. The scope of application that is established is of the national territory except the Canary Islands, Ceuta and Melilla. However, intermediate taxes on alcohol and derivatives will be required in the Canary Islands.

Consequently, and according to article 6 of the Special Tax Law, its own circumstances of non-subjection are determined on extraordinary occasions when the loss of products occurs due to force majeure or destruction.

The accrual of the special tax according to the Law already cited in its article 7, declares that it will occur at the time of leaving the factory, or deposit or self-consumption depending on the case. The taxpayer, according to article 8 of the Law of Special Taxes, is attributed to both natural and legal persons, likewise in article 9 it establishes a regime of tax exemptions in international organizations, armed forces, etc.

\subsection{Purpose of the Special Tax: its extra-fiscal function}

In order not to expand further on the characteristics of the tax, we have to focus on its purpose, as a special tax, to concur with another tax, as we already know, with the Value Added Tax. This double taxation has its justification in the objective of the tax itself. In the explanatory memorandum of the Special Tax Law, the need for this tax together with the VAT is justified in the application of certain products such as hydrocarbons, electricity, alcohol, etc., because they have high social costs, both environmental and health. Therefore, they must be taxed by consumers, thus fulfilling an extra-fiscal function as a dissuasive instrument that limits or reduces their consumption. It assumes in its scope that this tax will be applied together with another tax, Value Added Tax, increasing it, thus insisting on its justification.

If we take into account that the function of the tax in a State of Law is not simply to collect (Barquero, 2002, pp. 431-437), we thus have the concept of the extra-fiscal function of the tax, since this special tax has the apparent purpose of dissuading, encouraging or motivating certain conducts in favor of the general interest. This is where the dual functionality of the tax resides, its high collection and consequently its correction in the behavior of the consumer or user, this high tax being limited to the non-confiscatory 
principle declared by the Spanish Constitution, mitigating this double taxation in certain taxable events of rational way (Ríos, 2008, p. 139). However, this extra-fiscal function should not be based exclusively on a high tax for the consumer, but according to article 43.2 of the Spanish Constitution, public bodies may establish other dissuasive measures that promote such extra-fiscal function (campaigns to promote the use of renewable energies, subsidies for the purchase of hybrid or electric vehicles, among others) and not only based on the economic increase of the product.

In certain products such as the use of electricity or hydrocarbons, due to their essential nature, their extra-fiscal function is meaningless and has exclusively a collection objective, so when raising the tax on these products, no matter how much extra-fiscal appearance that possess, the only thing that is intended is to fill the state coffers (López, 2020b).

At this point, we can verify that, on some occasions, the alleged extrafiscal measures are supported by a double standard of the State, dissuading a behavior, but in turn collecting, since with such measures it is proven that the consumption of these products has not declined. As proof of this we can see it in the different economic studies on the behavior of users in relation to some products, where an increase in the consumption of alcohol (El Independiente, 2021), tobacco (Health web portal, 2021) (increases in Spain), hydrocarbons (Electronic economic journal, 2021), among others, is observed, demonstrating that the extra-fiscal nature of excise duties does not fulfill its mission despite its high burden.

\subsection{The Confiscation of Special Taxes}

Consequently, the application of special taxes may suggest that due to the lack of effectiveness in its extra-fiscal function and its double taxation in the collection with such unjustifiably high prices, it does not fulfill its mission, even being considered that it violates principles based on tax justice and economic capacity, leaving into question such essential concepts contained in the Spanish Constitution in its article 31.1 as that of non-confiscation. This term, included as inadmissible, is defined as ambiguous as the actual percentage necessary to consider it as such is not established exactly, and even jurisprudentially. Likewise, not only from the point of view due to its high taxation but where it is directed, since being an indirect tax, it absolutely dispenses with the circumstance of the economic capacity of the subject, and, therefore, it may be confiscatory or not depending on who pays it and their financial resources. As the Professor of Financial and Tax Law states (López, 2018, pp. 
23-54) when one quota is included over another, that is, the application of two taxes, the Value Added Tax and the Special Tax, taxing the product doubly does not respect the principle economic capacity of the subject.

\subsection{The European tax harmonization of Special Taxes}

The European Union, in an attempt to harmonize taxation of its Member States, has established different rules to unify the prices of products in all its Member States or at least make the amounts as close as possible, as proposed in Article 113 of the TFEU, where it establishes the need to harmonize taxes to guarantee the establishment and proper functioning of markets, as stated by the Professor of Financial and Tax Law (Mata, 2018, pp. 41-64). To this end, different Directives have been developed with common guidelines on specific matters that unify, as far as possible, their quantification. Energy products and electricity, regulated by Directive 2003/96 / CE; Alcohol and alcoholic beverages, regulated by Directives 92/83 / CEE and 92/84 / CEE; Tobacco work, regulated by Directive 2011/64 / EU; with the essential objective of guaranteeing a good functioning in the European space.

However, this harmonization has not been exempt from consequences, especially in our legal system, the Spanish, since its application, as we have already verified, to the principles of economic capacity of the obligor and therefore does not comply with tax justice, an essential element of our constitutional regulation on tax matters. This harmonization obliges the imposition of one tax on another, which, when applying said tax on consumption tax, VAT, to another, the special one, supposes a situation of superimposition, as pointed out by the Professor of Financial and Tax Law (López, 2018, pp. 2354). Therefore, such harmonization is detrimental to the pocket of the Spanish citizen, especially those lacking in resources, which have not been taken into account in the application of this tax, something contrary to what our constitutional rule stipulates.

\section{Future research directions}

In order to achieve a better analysis of the incidence of special taxes in the Spanish legal system, its European harmonization and its respect for the constitutional principles of the state, the study of the future transposition derived from the new Directive (EU) 2020 is proposed. It establishes the general regime of special taxes, since it intends to continue with the fiscal harmonization of the Member States, guaranteeing their functioning of the internal 
market by applying new telematic and administrative measures, however, it will be necessary to wait for the period granted by the Union for its regulation.

\section{Conclusions}

To conclude, after the study carried out on Special Taxes and the incidence of the Tax Harmonization Directive in the Spanish State, it has been found that it collides with the constitutional tax principles, since it taxes certain products with double taxation in excess, totally disregarding the subjective element of the tax, its circumstances and conditions, taxing it in a linear way as it is an indirect tax, eliminating the personal consideration of the principle of economic capacity in its entirety, negatively affecting the extra-fiscal function to those lacking resources especially.

Therefore, such harmonization, although necessary in terms of guaranteeing the free circulation of markets, should consider the circumstances of the obligor more directly and make compatible both the national principles of tax justice with the proper functioning of European markets through not only economic measures, since, in a way, it reveals a marked collection character rather than fulfilling its extra-fiscal purpose as a corrective means.

\section{Sánchez Ballesteros Vanesa}

Doktor pravnih nauka, Departman za građansko, finansijsko i poresko pravo, Univerzitet u Jaén-u, Španija

\section{ŠPANSKI POSEBNI POREZI I PORESKO USKLAĐIVANJE EVROPSKE UNIJE}

REZIME: Ako se posebni porezi rađaju sa osnovnim ciljem promovisanja ograničenja potrošnje određenih proizvoda koji proizilaze iz njihovog razornog društvenog ili ekološkog uticaja, potrebno je razmisliti o njihovoj visokoj ceni koja je nastala transpozicijom Direktive (EU) 2020. /262 Saveta, od 19. decembra 2019. godine, kojom se utvrđuje opšti režim posebnih poreza i njihovog oporezivanja. Ako je cilj pomenute Direktive postizanje fiskalne harmonizacije, potrebno je razmotriti efekte koji nastaju kada njena primena u španskoj državi direktno dođe u koliziju sa ekonomskim kapacitetima i poreskom pravdom, jer ovi principi mogu biti 
bez sadržaja i ugrožavati u većoj ili manjoj meri protiv druge osnovne nekonfiskatorske naplate poreza. Iz tog razloga, u ovom radu će se analizirati neka pitanja vezana za njegovu kvantifikaciju i rezultate koji nastaju u okviru harmonizacije sa pravilima Evropske unije. Uzimajući u obzir da naši ustavni principi mogu biti dovedeni u pitanje, postaviće se različita pitanja o dvostrukom oporezivanju proizvoda na koje ti porezi svakako utiču i kakav je kontekst društvenih reperkusija u situaciji da se ovakav sistem oporezivanja ne primenjuje.

Ključne reči: poseban porez, ekstraporeski, konfiskatorski, harmonizacija.

\section{References}

1. Barquero Esteban, J. M. (2002). La función del tributo en el Estado social y democrático de Derecho. Centro de Estudios Constitucionales. Madrid, pp. 431-437

2. El Independiente. Downloaded 2021, Juni 3 from https://www.elindependiente.com/sociedad/2020/11/27/espana-fue-el-pais-donde-mas-crecioel-consumo-de-alcohol-durante-el-confinamiento/

3. Electronic economic journal. Downloaded 2021, June 17 from https:// revistas.eleconomista.es/energia/2021/mayo/el-consumo-de-carburantes-en-espana-sube-un-15-tras-el-fin-del-estado-de-alarma-NI7802935

4. Health web portal. Downloaded 2021, June 10 from https://www.consalud.es/pacientes/dias-mundiales/las-alarmantes-cifras-del-tabaquismoen-espana_64471_102.html

5. Law 38/1992 Special Taxes, from December, 28, State Official Bulletin BOE, from December, 29

6. Law 58/2003 General Taxation, from December, 17, State Official Bulletin BOE, from December, 18

7. López Espadafor, C. M. (2018). La inclusión de los Impuestos Especiales en la base imponible del IVA como situación de sobreimposición. Revista Quincena Fiscal. (1), pp. 23-54

8. López Espadafor, C. M. (2020a). Dimensión fiscal del derecho de la propiedad: Los postulados del Derecho de la Unión Europea en materia tributaria desde la perspectiva del Derecho de propiedad. Madrid: Dykinson

9. López Espadafor, C.M. (2020b). Impuestos extrafiscales: cuando el Estado trata de influir en el comportamiento ciudadano. The Conversation, Downloaded 2021, September 11 from https://theconversation.com/ 
impuestos-extrafiscales-cuando-el-estado-trata-de-influir-en-el-comportamiento-ciudadano-140214

10. Mata Sierra, M. T. (2018). La armonización fiscal de los Impuestos Especiales. Revista Jurídica de la Universidad de León, (5), pp. 41-64

11. Ríos Granados, G. (2008). La función del tributo en el estado moderno de derecho. Instituto de investigaciones jurídicas. México

12. Sainz de Bujanda, F. (1991). Lecciones de Derecho Financiero. Madrid: Universidad Complutense de Madrid

13. Spanish Constitution, 29. December 1978. Official State Bulletin 